\title{
PENGARUH THIN CAPITALIZATION RULE PADA LEVERAGE PERUSAHAAN MASUK BURSA DI INDONESIA
}

\author{
Muhammad Rheza Ramadhan ${ }^{1}$ \\ * Kementerian Keuangan Republik Indonesia \\ *rhezakz@gmail.com ${ }^{l}$ \\ Satria Agus Frandyanto ${ }^{2}$ \\ * Kementerian Keuangan Republik Indonesia \\ *satriafran@gmail.com ${ }^{2}$ \\ Riko Riandoko ${ }^{3}$ \\ * Prodi Perpajakan, Politeknik Keuangan Negara-STAN \\ *riandoko@stan.ac. $i^{3}$
}

\begin{abstract}
This research finds the effect of thin capitalization rule implementation to company leverage in Indonesia. This study used leverage data in 2015 (before the implementation) and 2016 (after the implementation). The data was processed using paired sample t-test. Based on hand-collected sample of 69 publicity-listed indonesian firms for the 2015 and 2016 year, our paired sample t-test result, descriptive statistic, and correlation test result show that thin capitalization rule can reduce company leverage by $73,8 \%$.
\end{abstract}

Abstract

Keywords: thin capitalization, tax avoidance, tax aggressiveness, transfer pricing, leverage

\section{Pendahuluan}

Dalam dunia bisnis, telah lama diketahui bahwa perusahaan multinasional dapat menggunakan hutang internal untuk menggeser laba dari negara dengan tarif pajak rendah ke negara dengan tarif pajak tinggi (Mardan, 2013). Oleh karena itu, banyak negara mencoba untuk melakukan pengaturan terkait thin capitalization untuk membatasi penggunaan hutang internal sebagai alat untuk melakukan penghindaran pajak. Pengaturan ini dimulai oleh negara Kanada yang telah mengatur terkait dengan thin capitalization pada tahun 1971 dan pada tahun 2015 sudah dua per tiga negara yang tergabung dalam OECD menerapkan thin capitalization rule (Buttner et al., 2012).

Praktek adanya thin capitalization di Indonesia pun juga sudah disadari sejak lama oleh pemerintah Indonesia, terbukti, pada tahun 1983 dalam pasal 18 ayat $1 \mathrm{UU} \mathrm{PPh}$ telah terdapat general anti avoidance rule untuk thin capitalization yang kemudian dilanjutkan dengan dikeluarkannya KMK1002/KMK.04/1984 yang mengatur bahwa debt to equity ratio maksimal perusahaan adalah 3:1. Sayangnya, pemberlakuan aturan ini tertunda selama 30 tahun sehingga selama waktu tersebut, DJP tidak memiliki aturan teknis yang dapat menjerat wajib pajak yang menggunakan thin capitalization sebagai teknik penghindaran pajaknya. Hal tersebut menyebabkan praktik penghindaran pajak (salah satunya dengan skema thin capitalization) marak dilakukan oleh wajib pajak (khususnya Penanaman Modal Asing) di Indonesia. Direktur Pemeriksaan dan Penagihan Direktorat Jenderal Pajak, Edi Slamet Irianto, menyatakan "Dari keseluruhan PMA yang ada, sebesar 28\% mengalami kerugian, sekitar 3918 PMA rugi selama 1-2 tahun dan 1150 PMA rugi selama 3-5 tahun." Selanjutnya, seperti yang diliput oleh Liputan 6 (2016), Direktur Jenderal Pajak, Ken Dwijugiasteadi, menyatakan bahwa sebanyak 2000 PMA telah merugi selama 10 tahun. Mekar Satria Utama, Direktur Penyuluhan, Pelayanan, dan Hubungan Masyarakat, Direktorat Jenderal Pajak, sebagaimana dikutip oleh CNN Indonesia (2016), menambahkan bahwa 2000 PMA yang merugi tersebut rata-rata menggunakan modus transfer pricing yang salah satu tekniknya dapat dilakukan dengan thin capitalization.

Pada tahun 2015, akhirnya keluarlah Peraturan Menteri Keuangan Nomor PMK-169/PMK.010/2015 yang mengatur bahwa batasan debt to equity ratio maksimal 4:1. Hanya saja, keluarnya peraturan ini tidak lepas dari adanya kritik, salah satu kritik 
dikeluarkan oleh Darussalam dan Kristiaji (2015) yang mengatakan bahwa seharusnya peraturan mengenai debt to equity ratio harus mempertimbangkan arm's length transaction dengan melihat fakta bisnis sehingga mungkin saja wajib pajak dapat memiliki debt to equity ratio melebih $4: 1$ asalkan hal tersebut sesuai dengan fakta bisnis yang ada.

Penelitian yang ada sebelumnya menyatakan bahwa adanya thin capitalization rule menyebaban perubahan struktur modal pada perusahaan di Amerika Serikat dengan berkurangnya hutang sebesar $43 \%$ (Blouin et. al., 2014). Menariknya, penelitian yang dilakukan oleh Buettner et al. (2012) menyatakan bahwa meskipun hutang internal (kepada pihak afiliasi) berkurang, namun hal ini menambah adanya hutang eksternal (non afiliasi) sehingga jumlah leverage menjadi tetap.

Berdasarkan latar belakang yang telah disampaikan sebelumnya, penulis tertarik untuk melakukan penelitian mengenai pengaruh adanya thin capitalization rule terhadap leverage (yang diukur dengan menggunakan debt to equity ratio) pada perusahaan Masuk Bursa di Indonesia. Penelitian ini bertujuan untuk mengidentifikasi apakah terdapat perbedaan signifikan leverage perusahaan sebelum dan setelah adanya PMK-169/PMK.010/2015 serta untuk melihat pengaruh PMK-169/PMK.010/2015 dalam mengubah leverage perusahaan di Indonesia.

\section{Kajian Pustaka dan Pengembangan Hipotesis \\ Leverage \\ Leverage dapat diartikan sebagai kemampuan} suatu perusahaan melunai hutang dengan menggunakan aset atau ekuitas yang dimilikinya. Karena adanya perbedaan antara perlakukan dividen dengan bunga dalam undang-undang perpajakan di Indonesia maka semakin besar leverage suatu perusahaan, perusahaan tersebut akan semakin mengambil keuntungan dari sifat alamiah utang untuk melakukan tax avoidance (Hines, 1996; Richardson, et. al., 1998; Newberry dan Dhaliwal, 2001). Hal ini dapat dilihat dalam perusahaan dengan debt to equity ratio tinggi yang lebih menerapkan tax aggresiveness dibandingkan dengan perusahaan dengan debt to equity ratio rendah (Bernard et al., 2006).

\section{Pengaruh Thin Capitalization Rule terhadap Leverage Perusahaan}

Penelitian di Amerika Serikat menunjukan bahwa thin capitalization rule dapat menurunkan hutang perusahaan di Amerika Serikat sebesar 43\% (Blouin et al., 2014). Adanya penerapan thin capitalization rule di Indonesia juga memiliki tujuan yang serupa dengan yang berlaku di Amerika Serikat yaitu agar perusahaan membatasi hutang dan mengganti struktur pembiayaan menjadi modal saham. Oleh karena itu, berdasarkan landasan teori di atas dan penelitian terdahulu yang ada, penulis membuat suatu hipotesis:

$\mathrm{H1}$ : Adanya thin capitalization rule menyebabkan perubahan yang signifikan pada leverage perusahaan di Indonesia

\section{Metode Penelitian}

\section{Ruang Lingkup Penelitian}

Ruang lingkup penelitian ini mengambil objek penelitian seluruh laporan keuangan masuk bursa pada tahun 2015 dan 2016 dengan membatasi pada perusahaan yang laporan tahunannya telah terdapat dalam situs Bursa Efek Indonesia.

\section{Teknik Pengumpulan Data}

Pengumpulan data dilakukan dengan mengambil total nilai hutang dan ekuitas perusahaan sampel pada tahun 2015 dan 2016 menggunakan data laporan tahunan yang terdapat dalam situs Bursa Efek Indonesia.

\section{Variabel Penelitian dan Definisi Operasional Variabel}

Variabel penelitian yang penulis analisis adalah leverage. Variabel ini menggambarkan banyaknya utang yang dimiliki oleh perusahaan sebagai instrumen pendanaannya (Richardson et al., 2013). Variabel ini diukur dengan menggunakan proksi variabel Debt to Equity Ratio hal ini disdasari oleh dipergunakannya Debt to Equity Ratio sebagai dasar dalam menghitung leverage perusahaan pada PMK-169/PMK.010/2015.

\section{Teknik Analisis}

Prosedur analisis data dilakukan dengan menggunakan uji beda terhadap leverage tahun 2015 (sebelum pemberlakuan PMK-169/PMK.010/2015) dengan leverage tahun 2016 (setelah pemberlakuan 
PMK-169/PMK.010/2015). Alat statistik yang dapat digunakan untuk menguji hipotesis adalah uji t sampel berpasangan (paired sample t-test) (Ghozali, 2016). Pengujian dilakukan menggunakan aplikasi statistik SPSS 23. Sebelum dilakukan pengujian uji $t$, penulis juga melakukan analisis statistik deskriptif untuk melihat persebaran data. Setelah dilakukan uji t sampel berpasangan, penulis juga melakukan uji korelasi untuk melihat kontribusi thin capitalization rule dalam mengubah leverage perusahaan.

\section{Hasil dan Pembahasan}

\section{Pemilihan Sampel}

Pengambilan sampel dilakukan dengan menggunakan metode purposive sampling dengan mengecualikan perusahaan yang laporan tahunannya belum ada pada situs bursa efek indonesia, perusahaan yang memiliki Debt to Equity Ratio negatif, dan perusahaan yang termasuk dalam outlier sehingga didapatkan sampel sebagai berikut:

Tabel 1

Pemilihan Sampel

\begin{tabular}{|l|r|}
\hline $\begin{array}{l}\text { Perusahaan masuk bursa } \\
\text { tahun 2016 }\end{array}$ & 537 Perusahaan \\
\hline $\begin{array}{l}\text { Perusahaan yang laporan } \\
\text { tahunannya belum terdapat } \\
\text { dalam situs bursa efek } \\
\text { Indonesia }\end{array}$ & 461 Perusahaan \\
\hline $\begin{array}{l}\text { Perusahaan yang memiliki } \\
\text { Debt to Equity Ratio Negatif }\end{array}$ & 5 Perusahaan \\
\hline $\begin{array}{l}\text { Perusahaan yang termasuk } \\
\text { dalam outlier }\end{array}$ & 2 Perusahaan \\
\hline Perusahaan sampel & 69 Perusahaan \\
\hline
\end{tabular}

\section{Statistik Deskriptif}

Analisis statistik deskriptif dilakukan guna melihat persebaran data sampel. Analisis statistik deskriptif dilakukan dengan menggunakan aplikasi SPSS 23 dengan melihat nilai rata-rata (mean) dan standar deviasi dari perusahaan sampel. Hasil dari analisis statistik deskriptif dapat dilihat pada tabel 2 sebagai berikut:
Tabel 2

\section{Statistik Deskriptif}

\begin{tabular}{|l|c|r|r|r|}
\hline & Mean & $\mathrm{N}$ & $\begin{array}{c}\text { Std. } \\
\text { Deviation }\end{array}$ & $\begin{array}{c}\text { Std. Error } \\
\text { Mean }\end{array}$ \\
\hline DER2015 & 1,5578 & 69 & 1,54471 &, 18596 \\
DER2016 & 1,2651 & 69 & 1,10345 &, 13284 \\
\hline
\end{tabular}

Dalam tabel 2 dapat dilihat bahwa rata-rata Debt to Equity perusahaan sampel meningkat dari tahun 2015 ke tahun 2016 dengan nilai rata-rata tahun 2015 sebesar 1,5578 dan tahun 2016 sebesar 1,2651.

\section{Pengujian Hipotesis}

Pengujian hipotesis dilakukan dengan menggunakan paired sample $t$ test melalui aplikasi statistik SPSS 23. Dalam penelitian ini, penulis menggunakan pendekatan Null Hypothesis Significance Testing (NHST). Untuk menentukan apakah H0 diterima atau ditolak, penulis akan menggunakan p-value (dalam aplikasi IBM SPSS 23 tertulis sig) dengan asumsi HO adalah benar (Field, 2013, 2.6.1.3). Oleh karena itu, parameter yang penting untuk menguji hipotesis dalam penelitian ini adalah pada signifikansi variabel yang diteliti. Tingkat kepercayaan yang digunakan dalam penelitian ini adalah $95 \%$ yang artinya $\mathrm{H0}$ akan ditolak jika nilai probabilitas ( $s i g$ dalam aplikasi IBM SPSS 23) bernilai lebih besar dari 0,05.

Berdasarkan analisis paired sample $t$ test didapatkan hasil sebagai berikut:

Tabel 3

Paired Sample t-test

\begin{tabular}{|c|c|c|c|}
\hline & $t$ & $d f$ & $\begin{array}{l}\text { Sig. (2- } \\
\text { tailed) }\end{array}$ \\
\hline $\begin{array}{l}\text { DER2015 } \\
\text { DER2016 }\end{array}$ & 2,957 & 68 & ,004 \\
\hline
\end{tabular}

Dalam tabel 3 dapat dilihat bahwa nilai sig.adalah 0,004 yang berarti berada di bawah 0,05 yang artinya $\mathrm{H} 0$ harus ditolak yang berarti bahwa adanya thin capitalization rule memberikan perubahan signifikan pada leverage Perusahaan Masuk Bursa di Indonesia.

Kemudian, untuk melihat kontribusi thin capitalization rule dalam mengubah leverage perusahaan di Indonesia, penulis melakukan uji korelasi dengan hasil sebagai berikut: 
Tabel 4. Uji Korelasi

\begin{tabular}{|c|c|c|c|}
\hline & $\mathrm{N}$ & $\begin{array}{c}\text { Correlati } \\
\text { on }\end{array}$ & Sig. \\
\hline $\begin{array}{l}\text { DER2015 } \\
\& \\
\text { DER2016 }\end{array}$ & 69 & 859, & 000, \\
\hline
\end{tabular}

Berdasarkan hasil tersebut dapat dilihat nilai correlation sebesar 0,859 dan $R$-square sebesar 0,738 yang artinya perubahan leverage perusahaan di Indonesia $73,8 \%$ disebabkan oleh thin capitalization rule dan $26,2 \%$ disebabkan oleh faktor lainnya.

\section{Pembahasan}

Berdasarkan hasil pengujian hipotesis pada bagian sebelumnya diketahui bahwa adanya thin capitalization rule dapat memberikan perubahan signifikan pada leverage Perusahaan Masuk Bursa di Indonesia. Hal ini sejalan dengan hasil penelitian yang dilakukan oleh Blouin et al. (2014) yang menyebutkan bahwa thin capitalization rule dapat menurunkan nilai hutang yang tentunya menurunkan nilai Debt to Equity Ratio. Kemudian, berdasarkan statistik deskriptif juga dapat dilihat bahwa thin capitalization rule dapat menurunkan leverage perusahaan di Indonesia sesuai dengan tujuan dari thin capitalization rule.

Berdasarkan hasil uji korelasi juga dapat dilihat bahwa thin capitalization rule memberikan perubahan pada leverage perusahaan di Indonesia sebesar 73,8\% dan $26,2 \%$ disebabkan oleh faktor lainnya. Hal ini menandakan bahwa thin capitalization rule sudah dapat menurunkan leverage perusahaan di Indonesia dengan efektif.

\section{Simpulan}

Dalam dunia bisnis, baik di Indonesia maupun di dunia internasional, perusahaan (terutama multinasional) cenderung memanfaatkan adanya perbedaan perlakuan perpajakan antara dividen dengan bunga untuk melakukan penghindaran pajak menggunakan skema thin capitalization. Oleh karena itu, banyak negara mengeluarkan peraturan mengenai thin capitalization rule. Indonesia, pada tahun 2015, juga telah mengeluarkan thin capitalization rule yaitu pada PMK-169/PMK.010/2015 yang membatasi nilai Debt to Equity Ratio menjadi 4:1.

Berdasarkan uji paired sample t test pada 69 perusahaan masuk bursa di Indonesia, didapatkan bahwa thin capitalization rule dapat memberikan pengaruh signifikan pada leverage perusahaan masuk bursa di Indonesia. Berdasarkan hasil uji korelasi juga dapat dilihat bahwa thin capitalization rule memberikan perubahan pada leverage perusahaan di Indonesia sebesar $73,8 \%$ dan $26,2 \%$ disebabkan oleh faktor lainnya. Hal ini menandakan bahwa thin capitalization rule sudah dapat menurunkan leverage perusahaan di Indonesia dengan efektif.

\section{Keterbatasan Penelitian}

Dalam penelitian ini terdapat beberapa keterbatasan yang sebaiknya dapat diperbaiki oleh peneliti selanjutnya dalam hal ini, diantaranya:

1. Penelitian dilakukan dengan sampel yang terlalu sedikit karena belum tersedianya data dalam situs Bursa Efek Indonesia;

2. Penelitian dilakukan dengan menggunakan metode paired sample t-test, yang masih bisa dikembangkan dengan metode lainnya yang lebih kompleks seperti difference in difference.

3. Penelitian dilakukan dengan tidak memisahkan antara perusahaan yang memiliki debt to equity ratio di atas 4:1 dan di bawah 4:1.

\section{Saran}

Berdasarkan hasil penelitian di atas penulis memberikan saran kepada berbagai pihak sebagai berikut:

Bagi Direktorat Jenderal Pajak:

1. Perlu dilakukan reviu terhadap PMK169/PMK.010/2015 dengan mempertimbangkan aspek kewajaran usaha (arm's length principle) dalam penentuan Debt to Equity Ratio yang wajar bagi perusahaan

Bagi Peneliti Selanjutnya:

1. Penelitian dapat dilakukan kembali dengan sampel yang lebih banyak ketika seluruh data laporan tahunan tahun 2016 sudah terdapat pada situs Bursa Efek Indonesia;

2. Penelitian dapat dilakukan dengan metode yang lebih kompleks seperti difference in difference;

Penelitian dapat dilakukan dengan memisahkan antara perusahaan yang memiliki debt to equity ratio di atas 4:1 dan di bawah 4:1. 


\section{Referensi}

[1] Bernard, Andrew B., J. Bradford Jensen, dan Peter K. Schott. 2006. "Transfer Pricing by U.S.Based Multinational Firms." NBER Working Paper 12493 http://www.nber.org/papers/w12493.

[2] 2016. CNN Indonesia. Oktober 30. http://www.cnnindonesia.com/ekonomi/2016032 8115246-78-119992/djp-bongkar-motif-2000perusahaan-yang-kemplang-pajak.

[3] Field, Andy. 2013. Discovering Statistc Using IBM SPSS Statistics (4th Edition). London: SAGE Publications.

[4] Ghozali, Imam. 2016. Aplikasi Analisis Multivariate dengan Program IBM SPSS 23. Semarang: Badan Penerbit Universitas Diponegoro.

[5] Hines, James R. 1996. "Tax policy and the activities of multinational corporations." Working Paper http://www.nber.org/papers/w5589.

[6] Bloin, Jennifer, Harry Huizinga, dan Luc Laeven. 2014. "Thin Capitalization Rules and Multinational Firm Capital Structure." CEFR Discussion Paper 9830 1-2.

[7] 2016. Liputan 6. September 19. http://bisnis.liputan6.com/read/2469089/2000perusahaan-asing-gelapkan-pajak-selama-10tahun.

[8] Mardan, Mohammed. 2013. "The Effects of Thin Capitalization Rules when Firms are Financially Constrained." Norwegian Center of Taxation.

[9] Newberry, Kaye J., and Dan S. Dhaliwal. 2001. "Cross-jurisdictional income shifting by U.S. multinationals: evidence from international bond offerings." Journal of Accounting Research 39 (3) 643-662.

[10]Richardson, Grant, Dean Hanlon, dan Les Nethercott. 1998. "Thin capitalization: an AngloAmerican comparison." The International Tax Journal 24 (2) 36-66.

[11]Richardson, Grant, Grantley Taylor, dan Roman Lanis. 2013. "Determinants of Transfer Pricing Aggressiveness." Journal of Contemporary Accounting \& Economics 9 136-150.

[12]T. Buttner, M. Overesch, U Schreiber, G. Wamser. 2012. "The Impact of Thin Capitalization Rules on The Capital Structure of
Multinational Firms." Journal of Public Economics 96 930-938. 